\title{
Meningkatkan kemandirian dan hasil belajar peserta didik dengan menggunakan Mobile Learning PERSIKA berbasis Ispring Suite 9 \\ (A useful mobile base learning media in the Covid-19 era)
}

\author{
Dwi Ike Purnamasari, Heny Kusdiyanti* \\ Universitas Negeri Malang, Jl. Semarang No. 5 Malang, Jawa Timur, Indonesia \\ *Penulis korespondensi, Surel: heny.kusdiyanti.fe@um.ac.id
}

Paper received: 7-6-2021; revised: 21-6-2021; accepted: 28-6-2021

\begin{abstract}
Abstrak
Perkembangan teknologi saat ini berkembang begitu pesat dan semakin canggih di semua bidang, tak terkecuali di dunia pendidikan. Teknologi saat ini mulai dimanfaatkan di bidang pendidikan yaitu di sekolah baik oleh guru dan peserta didik sebagai alat penunjang berlangsungnya kegiatan pembelajaran. Dengan adanya hal itu maka diperlukan adanya pengembangan lebih lanjut pada media pembelajaran dengan memanfaatkan teknologi yang berkembang dengan cepat dan canggih ini. Pendidikan menjadi salah satu aspek yang terdampak pandemi Coronavirus Disease (Covid-19). Penyebaran virus ini terbilang sangat cepat di Indonesia sejak awal tahun 2020, dampak dari adanya covid-19, saat ini pembelajaran dilakukan secara daring (online), sehingga guru dituntut untuk kreatif serta inovatif dalam mengoptimalkan teknologi dalam kegiatan pembelajaran. Oleh karena itu, penelitian ini bertujuan untuk menghasilkan produk Mobile Learning PERSIKA berbasis iSpring Suite 9 untuk meningkatkan kemandirian dan hasil belajar peserta didik. Produk media pembelajaran yang dikembangkan terdapat enam menu dan fitur yang mempermudah penggunaan dalam pengoperasiannya Cakupan materi yang lengkap, serta ukuran file sebesar 7,91 MB dapat membantu peserta didik dalam meningkatkan kemandirian dan hasil belajar peserta didik. Penelitian dan pengembangan ini menggunakan model Research and Development Borg and Gall yang telah dimodifikasi. Teknik analisis data yang digunakan adalah deskriptif persentase hitung manual dan serta uji Mann-Whitney. Hasil penelitian dan pengembangan ini adalah Mobile Learning PERSIKA berbasis iSpring Suite 9 mata pelajaran Administrasi Umum yang bernama PERSIKA yang telah dinyatakan valid dan layak digunakan dalam pembelajaran Administrasi Umum Kompetensi dasar Menganalisis Persyaratan Personil Administrasi Kantor oleh ahli media, ahli materi, dan 6 siswa uji coba kelompok kecil serta terbukti terdapat perbedaan kemandirian dan hasil belajar secara signifikan pada uji coba kelompok besar dimana hasil tes kelas eksperimen lebih tinggi daripada kelas kontrol. Sehingga dapat disimpulkan bahwa PERSIKA layak dan efektif digunakan sebagai media pembelajaran untuk meningkatkan kemandirian dan hasil belajar Peserta didik pada mata pelajaran Administrasi Umum.
\end{abstract}

Kata kunci: penelitian dan pengembangan; media pembelajaran; mobile learning; ispring suite 9; kemandirian; hasil belajar.

\section{Pendahuluan}

Perkembangan teknologi saat ini berkembang begitu pesat dan semakin canggih di semua bidang, tak terkecuali di dunia pendidikan. Teknologi saat ini mulai dimanfaatkan di bidang pendidikan yaitu di sekolah baik oleh guru dan peserta didik sebagai alat penunjang berlangsungnya kegiatan pembelajaran. Dengan adanya hal itu maka diperlukan adanya pengembangan lebih lanjut pada media pembelajaran dengan memanfaatkan teknologi yang berkembang dengan cepat dan canggih ini. Pendidikan menjadi salah satu aspek yang terdampak pandemi Coronavirus Disease (Covid-19). Penyebaran virus ini terbilang sangat cepat di Indonesia sejak awal tahun 2020 (Krishnamurthy, 2020). Sehingga dalam aspek 
pendidikan diberlakukannya kegiatan Pembelajaran Jarak Jauh (PJJ). Secara tidak langsung Siswa tetap melakukan kegiatan pembelajaran secara daring (online) dengan bantuan media pembelajaran yang telah disiapkan oleh guru yang diharapkan kebijakan ini dapat mengurangi penyebaran rantai virus Covid-19 (Ratten and Jones, 2021). Pembelajaran jarak jauh diperlukan media pembelajaran yang tepat dengan memanfaatkan kemajuan dari teknologi agar tujuan pendidikan dapat tercapai (Muhson, 2010). Kemajuan teknologi merupakan sesuatu yang tidak dapat dihindari dari kehidupan, karena kemajuan teknologi berjalan mengikuti kemajuan dari ilmu pengetahuan yang semakin hari akan semakin berkembang, inovasi terbaru akan selalu muncul yang memberikan dampak positif dan manfaat bagi kehidupan manusia (Ngafifi, 2014). Sedangkan Media pembelajaran adalah alat bantu yang digunakan guru untuk membagi ilmunya kepada peserta didik (Priansa, 2017: 129). Media pembelajaran yang kini mulai beragam mengikuti perkembangan ilmu pengetahuan dan teknologi yaitu media pembelajaran berbasis elektronik yang saat ini telah dijadikan sebagai alternatif pembelajaran di Indonesia dalam melakukan kegiatan belajar dari rumah secara daring, salah satunya yaitu mobile learning.

Pemanfaatan Pembelajaran M-Learning diharapkan memudahkan peserta didik dalam mendapatkan materi yang mudah dipahami dan dikemas menggunakan media smartphone sehingga interaksi antara guru dan siswa tidak terhambat oleh jarak dan waktu dan hasil belajar peserta didik tetap maksimal (Purwanto and Ramadhan, 2015). Mobile Learning yang dikembangkan dalam penelitian ini yaitu Mobile Learning PERSIKA berbasis iSpring Suite 9. Media berbasis iSpring Suite 9 adalah media pembelajaran yang dapat diakses dimanapun, kapanpun, dan oleh siapapun dengan menggunakan software yang dapat digunakan untuk mengubah file presentasi menjadi bentuk flash yang sangat menarik. Selain itu pengembangan media pembelajaran mobile learning berbasis iSpring Suite 9 juga bertujuan agar pembelajaran tidak hanya berpusat kepada guru atau hanya sekedar membaca modul yang membuat peserta didik terkadang susah membayangkan apa yang dijelaskan oleh guru.

Beberapa penelitian sebelumnya yang juga membahas tentang tema ini adalah penelitian Meilasari (2019); Crompton \& Burke (2018); Damayanti, dkk (2018); Nurwijayanti, dkk (2018); Parsazadeh, dkk (2018); Rahmawati \& Mukminan (2017); Lin (2017); Prasetyo, dkk (2017); Suryanda, dkk (2016); Swandhana, dkk (2016) berdasarkan penelitian-penelitian tersebut dapat disimpulkan bahwa media pembelajaran mobile learning berbasis iSpring Suite 9 yang dapat diakses secara offline dan dapat meningkatkan kemandirian dan hasil belajar peserta didik.

Akan tetapi, berdasarkan hasil wawancara guru Mata Pelajaran Administrasi Umum kelas X OTKP diperoleh informasi bahwa pembelajaran di SMK Muhammadiyah 5 Kepanjen Kabupaten Malang dilakukan secara daring dan luring. Media pembelajaran yang dimanfaatkan adalah Google Classroom. sekolah juga menggunakan sistem gelombang yang mana setiap 1 kelas akan dibagi menjadi 2 gelombang dan waktu pembelajaran yang dipersingkat. Dengan masih adanya kegiatan pembelajaran secara daring dan waktu pembelajaran yang dipersingkat tersebut membuat waktu penyampaian materi yang diberikan pada peserta didik jauh lebih sedikit dan membuat peserta didik masih akan lebih banyak untuk belajar sendiri. Dari masalah tersebut Peneliti berinovasi membuat sebuah aplikasi pembelajaran yang dapat digunakan pada smartphone peserta didik untuk memaksimalkan kondisi yang saat ini terjadi. Peneliti berinovasi membuat sebuah aplikasi Mobile yang bisa diinstall pada handphone peserta didik dan bisa digunakan secara offline pada 
Mata Pelajaran Administrasi Umum. Aplikasi ini berisikan materi, latihan soal, video pembelajaran sehingga ketika peserta didik tidak ada jadwal pembelajaran secara luring, mereka dapat secara mandiri mempelajari dan mengerjakan latihan soal melalui aplikasi tersebut.

\section{Metode}

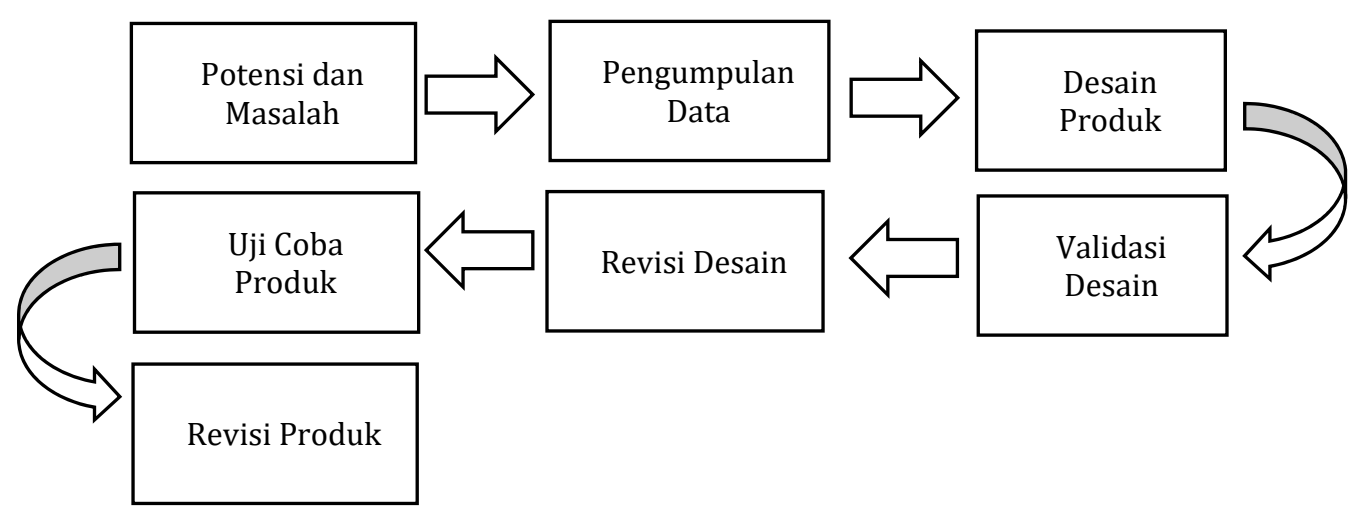

(Sumber: Sugiyono, 2009: 409)

\section{Gambar 1. Langkah-langkah penelitian}

Penelitian ini menggunakan model Research and Development Borg and Gall yang telah dimodifikasi menjadi tujuh langkah untuk mempersingkat waktu dan keadaan lapangan. Selain itu, peneliti juga merasa bahwa tujuan penelitian yaitu untuk menghasilkan produk, mengetahui kelayakan produk, dan mengetahui perbedaan kemandirian dan hasil belajar peserta didik yang menggunakan dengan yang tidak menggunakan produk yang dikembangkan.

Langkah pertama, peneliti melakukan penelitian dan pengumpulan informasi terkait permasalahan yang terjadi di sekolah dan kegiatan pembelajaran mata pelajaran Administrasi Umum. Langkah kedua, peneliti melakukan perencanaan terkait media yang akan dikembangkan. Langkah ketiga, peneliti mengembangkan format produk awal media pembelajaran yang akan dikembangkan dan dapat menjadi solusi atas permasalahan yang ditemukan pada langkah potensi dan masalah serta pengumpulan informasi serta mulai membuat media pembelajaran sesuai rancangan yang telah ditentukan pada langkah sebelumnya. Langkah keempat, media yang dihasilkan peneliti diuji kelayakan oleh para validator, yakni satu ahli media dan satu ahli materi dan uji coba pada peserta didik. Langkah kelima, merevisi desain agar lebih baik. Langkah keenam aplikasi yang telah dikembangkan di uji cobakan kepada validator ahli materi, ahli media dan kelompok kecil. Langkah ketujuh, revisi produk sesuai dengan kritik dan saran yang diberikan oleh responden agar produk semakin baik dan benar-benar layak digunakan sebagai media pembelajaran.

Data yang dihasilkan pada penelitian ini meliputi data kualitatif dan data kuantitatif, dimana data data kuantitatif terdiri dari data hasil validasi ahli materi, data hasil validasi media, data hasil uji coba kelompok kecil, dan data kemandirian serta hasil belajar peserta didik. Sedangkan data kualitatif didapatkan melalui penarikan kesimpulan berdasarkan saran, dan kritik dari ahli materi, ahli media, dan 6 siswa uji coba kelompok kecil. Data hasil validasi 
ahli materi, ahli media, dan uji coba kelompok kecil dianalisis menggunakan metode deskriptif persentase untuk menunjukkan tingkat kelayakan media pembelajaran. Sedangkan data kemandirian dianalisis menggunakan deskriptif persentase hitung manual dan hasil belajar peserta didik dianalisis menggunakan uji Mann-Whitney untuk menunjukkan perbedaan kemandirian dan hasil belajar peserta didik kelas eksperimen dan kelas kontrol.

\section{Hasil dan Pembahasan}

Produk yang dihasilkan dalam penelitian dan pengembangan ini adalah Mobile Learning PERSIKA berbasis iSpring Suite 9 pada mata Administrasi Umum. Mobile Learning PERSIKA berbasis iSpring Suite 9 terdiri dari menu yang dijelaskan melalui Gambar 2 berikut ini:

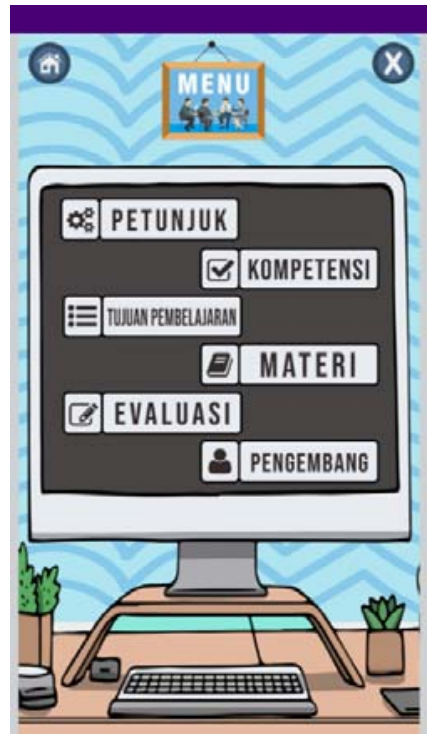

Gambar 2. Menu-menu dalam Aplikasi Persika

Setelah ada di "Halaman Menu”, pengguna dapat menuju Halaman Petunjuk seperti pada Gambar 3 yang berisi petunjuk menu yang tersedia.

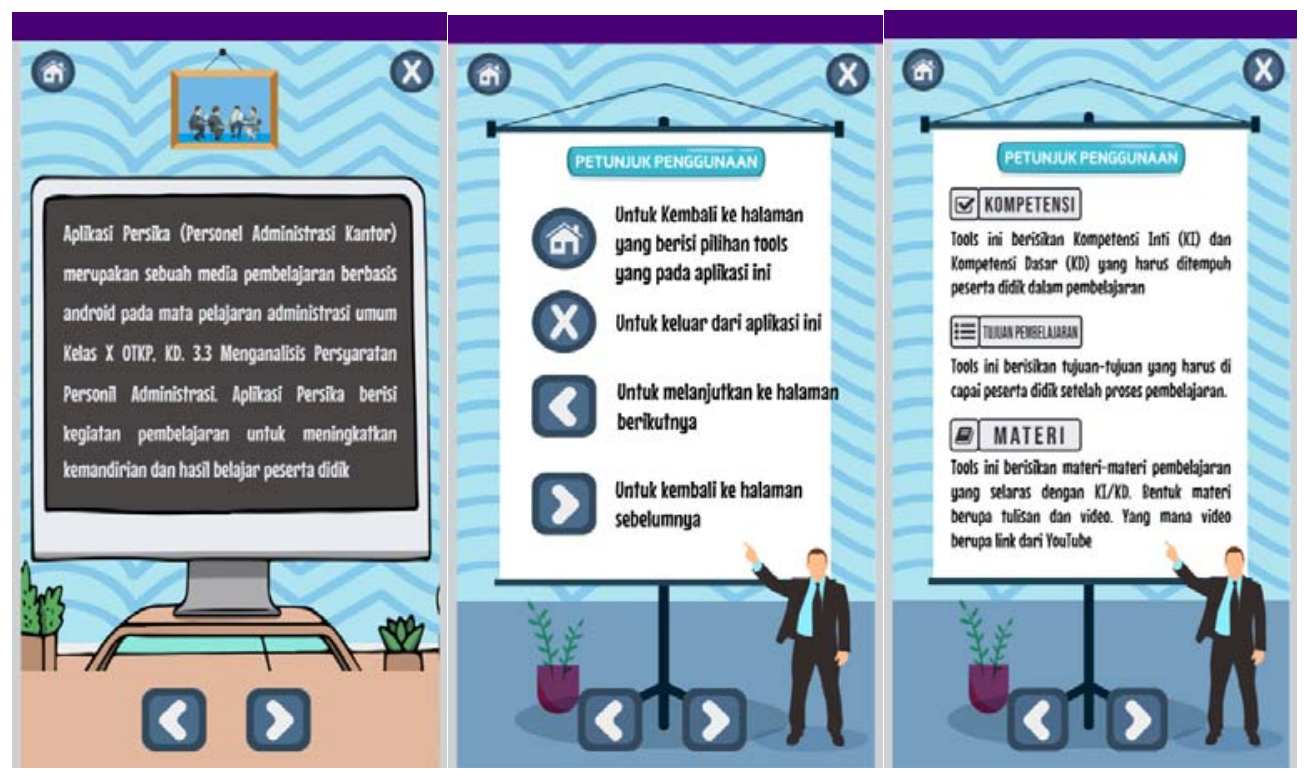




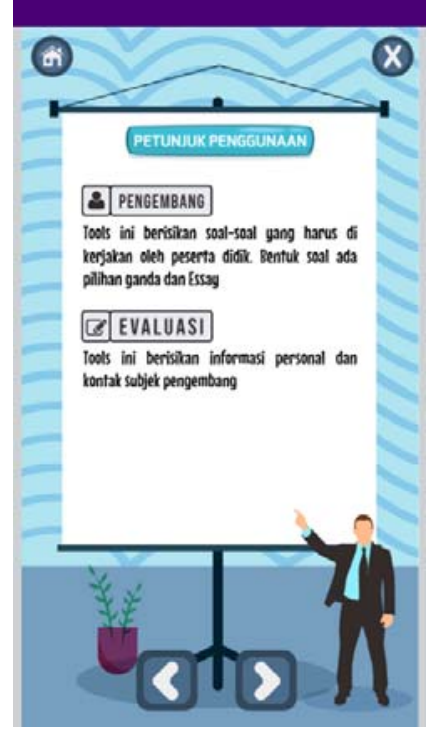

Gambar 3. Petunjuk menu aplikasi PERSIKA

Hasil validasi PERSIKA oleh ahli materi, ahli media, dan siswa uji coba kelompok kecil secara keseluruhan disajikan dalam Tabel 1 berikut ini:

Tabel 1. Data hasil validasi keseluruhan

\begin{tabular}{llll}
\hline No & \multicolumn{1}{c}{ Validasi } & Persentase & \multicolumn{1}{c}{ Kriteria Validitas } \\
\hline 1. & Ahli Materi & $80 \%$ & Valid \\
2. & Ahli Media & $80 \%$ & Valid \\
3. & Siswa Uji Coba Kelompok Kecil & $96 \%$ & Valid \\
& Rata-rata & $85 \%$ & Valid \\
\hline
\end{tabular}

Table used by permission (CPurnamasari, Dwi Ike, 2021. Data hasil validasi keseluruhan.

Berdasarkan Tabel 1, diketahui rata-rata persentase validasi secara keseluruhan sebesar 85\%, sehingga dapat disimpulkan bahwa media pembelajaran yang dikembangkan peneliti yakni Aplikasi PERSIKA, dinyatakan 'Valid' dan layak digunakan dalam pembelajaran Administrasi Umum di SMK Muhammadiyah 5 Kepanjen. Hal ini senada dengan penelitian sebelumnya, dimana hasil validasi ahli materi, ahli media dan uji coba kelompok kecil dijadikan dasar penentuan apakah media pembelajaran yang dikembangkan layak atau tidak digunakan dalam pembelajaran (Purwanto and Ramadhan, 2015).

Titik pengukuran berupa validitas mengacu pada hasil pengukuran yang dilakukan untuk mengetahui seberapa banyak aspek dalam ranah kuantitatif pada instrumen pengukuran yang dinyatakan dengan skor (Hendryadi, 2017). Aplikasi PERSIKA menyajikan enam menu dan fitur yang mempermudah penggunaan dalam pengoperasiannya Cakupan materi yang lengkap, serta ukuran file sebesar 7,91 MB dapat membantu peserta didik dalam meningkatkan kemandirian dan hasil belajar peserta didik. Efisiensi dan penggunaan teknologi yang efektif tergantung pada ketersediaan perangkat keras dan perangkat lunak (Afshari et al., 2009; Agbo, 2015; Gandal et al., 2000).

Sedangkan hasil uji hitung manual pada data kemandirian belajar kelas kontrol dan kelas eksperimen disajikan dalam Tabel 3 berikut ini: 


\subsection{Hitung Manual}

Hasil Uji Hitung Manual Data Kemandirian Belajar

Tabel 2. Data Hasil Uji Hitung Manual Kemandirian Belajar Kelas Kontrol

\begin{tabular}{|c|c|c|c|c|c|}
\hline $\begin{array}{c}\text { No } \\
\text { Absen }\end{array}$ & Indikator & (P) & (n) & $100 \%$ & $\begin{array}{c}P \\
100 \%\end{array}$ \\
\hline 1 & $\begin{array}{l}\text { Saya mampu mengelola strategi belajar } \\
\text { dengan cara membaca, meringkas, } \\
\text { membuat catatan, atau melihat materi } \\
\text { berupa video secara mandiri. }\end{array}$ & 127 & 170 & $100 \%$ & $75 \%$ \\
\hline 2 & $\begin{array}{l}\text { Saya mampu mengatur waktu belajar } \\
\text { secara mandiri. }\end{array}$ & 132 & 170 & $100 \%$ & $78 \%$ \\
\hline 3 & $\begin{array}{l}\text { Saya mampu mengatur tempat belajar } \\
\text { sehingga nyaman saat belajar. }\end{array}$ & 142 & 170 & $100 \%$ & $83 \%$ \\
\hline 4 & $\begin{array}{l}\text { Saya selalu mempersiapkan kebutuhan } \\
\text { yang diperlukan sebelum belajar. }\end{array}$ & 130 & 170 & $100 \%$ & $76 \%$ \\
\hline 5 & $\begin{array}{l}\text { Saya dapat mencari solusi Ketika } \\
\text { kesulitan memahami bahan ajar. }\end{array}$ & 136 & 170 & $100 \%$ & $80 \%$ \\
\hline 6 & $\begin{array}{l}\text { Saya selalu memperbaiki cara belajar } \\
\text { agar mendapatkan hasil belajar yang } \\
\text { baik. }\end{array}$ & 128 & 170 & $100 \%$ & $75 \%$ \\
\hline 7 & $\begin{array}{l}\text { Saya selalu mencari informasi } \\
\text { tambahan mengenai materi dari buku, } \\
\text { internet, atau sumber belajar lainnya. }\end{array}$ & 136 & 170 & $100 \%$ & $80 \%$ \\
\hline 8 & $\begin{array}{l}\text { Saya memiliki bahan ajar seperti buku, } \\
\text { print out dari internet, atau bahan ajar } \\
\text { lainnya. }\end{array}$ & 121 & 170 & $100 \%$ & $71 \%$ \\
\hline 9 & $\begin{array}{l}\text { Saya mengerjakan Latihan soal untuk } \\
\text { meningkatkan pemahaman belajar. }\end{array}$ & 131 & 170 & $100 \%$ & $77 \%$ \\
\hline Jumlah & & 1.183 & 1.530 & $100 \%$ & $77 \%$ \\
\hline
\end{tabular}

Table used by permission (CPurnamasari, Dwi Ike. 2021. Hasil uji normalitas kemandirian belajar.

Tabel 3. Data Hasil Uji Hitung Manual Kemandirian Belajar Kelas Eksperimen

\begin{tabular}{|c|c|c|c|c|c|}
\hline $\begin{array}{c}\text { No } \\
\text { Absen }\end{array}$ & Indikator & (P) & (n) & $100 \%$ & $\begin{array}{c}P \\
100 \%\end{array}$ \\
\hline 1 & $\begin{array}{l}\text { Saya mampu mengelola strategi belajar } \\
\text { dengan cara membaca, meringkas, } \\
\text { membuat catatan, atau melihat materi } \\
\text { berupa video secara mandiri. }\end{array}$ & 118 & 165 & $100 \%$ & $71 \%$ \\
\hline 2 & $\begin{array}{l}\text { Saya mampu mengatur waktu belajar } \\
\text { secara mandiri. }\end{array}$ & 143 & 165 & $100 \%$ & $87 \%$ \\
\hline 3 & $\begin{array}{l}\text { Saya mampu mengatur tempat belajar } \\
\text { sehingga nyaman saat belajar. }\end{array}$ & 145 & 165 & $100 \%$ & $88 \%$ \\
\hline 4 & $\begin{array}{l}\text { Saya selalu mempersiapkan kebutuhan } \\
\text { yang diperlukan sebelum belajar. }\end{array}$ & 146 & 165 & $100 \%$ & $88 \%$ \\
\hline 5 & $\begin{array}{l}\text { Saya dapat mencari solusi Ketika } \\
\text { kesulitan memahami bahan ajar. }\end{array}$ & 153 & 165 & $100 \%$ & $93 \%$ \\
\hline 6 & $\begin{array}{l}\text { Saya selalu memperbaiki cara belajar } \\
\text { agar mendapatkan hasil belajar yang } \\
\text { baik. }\end{array}$ & 148 & 165 & $100 \%$ & $90 \%$ \\
\hline
\end{tabular}




\begin{tabular}{llcccc}
\hline $\begin{array}{c}\text { No } \\
\text { Absen }\end{array}$ & \multicolumn{1}{c}{ Indikator } & (P) & (n) & $\mathbf{1 0 0 \%}$ & $\begin{array}{c}\mathbf{P} \\
\mathbf{1 0 0 \%}\end{array}$ \\
\hline 7 & $\begin{array}{l}\text { Saya selalu mencari informasi } \\
\text { tambahan mengenai materi dari buku, } \\
\text { internet, atau sumber belajar lainnya. } \\
\text { Saya memiliki bahan ajar seperti buku, } \\
\text { print out dari internet, atau bahan ajar }\end{array}$ & 150 & 165 & $100 \%$ & $91 \%$ \\
\hline & $\begin{array}{l}\text { lainnya. } \\
\text { Saya mengerjakan Latihan soal untuk } \\
\text { meningkatkan pemahaman belajar. }\end{array}$ & 152 & 165 & $100 \%$ & $88 \%$ \\
Jumlah & & 1.301 & 1.485 & $100 \%$ & $92 \%$ \\
\hline
\end{tabular}

Table used by permission (CPurnamasari, Dwi Ike. 2021. Hasil uji normalitas kemandirian belajar.

Pada Tabel 2 menunjukkan bahwa kelas kontrol memperoleh rata-rata skor $77 \%$ atau dalam kategori tingkat kemandirian belajar tinggi. Sedangkan pada Tabel 3 kelas eksperimen memperoleh rata-rata skor $88 \%$ atau dalam kategori kemandirian belajar tinggi. Meskipun kedua kelas memperoleh kategori kemandirian belajar tinggi namun kelas eksperimen selaku kelas yang menggunakan produk media pembelajaran berbasis android yakni aplikasi PERSIKA memperoleh persentase lebih baik daripada kelas kontrol.

Kelas eksperimen memperoleh persentase yang lebih baik daripada kelas kontrol di setiap aspeknya hal ini menunjukkan bahwa penerapan media pembelajaran ini yakni aplikasi PERSIKA mampu meningkatkan kemandirian belajar peserta didik. Peserta didik yang menggunakan aplikasi PERSIKA sebagai media pembelajaran akan memiliki keyakinan dan efikasi diri, motivasi intrinsik, motivasi ekstrinsik dan pengaturan pembelajaran yang lebih baik daripada peserta didik yang tidak menggunakan. Sehingga Mobile Learning yang dikembangkan efektif digunakan untuk meningkatkan kemandirian belajar peserta didik (Motiwalla, 2007; Rahmawati and Mukminan, 2017). Seperti Penelitian yang dilakukan oleh Tabuenca et al. (2015) bahwa pembelajaran berbasis mobile learning dapat membantu dirinya sendiri dalam melakukan pembelajaran seperti memanajemen waktunya.

Tampilan hasil analisis data hasil belajar peserta didik antara kelas kontrol dan eksperimen dapat dilihat pada Gambar 4 berikut:

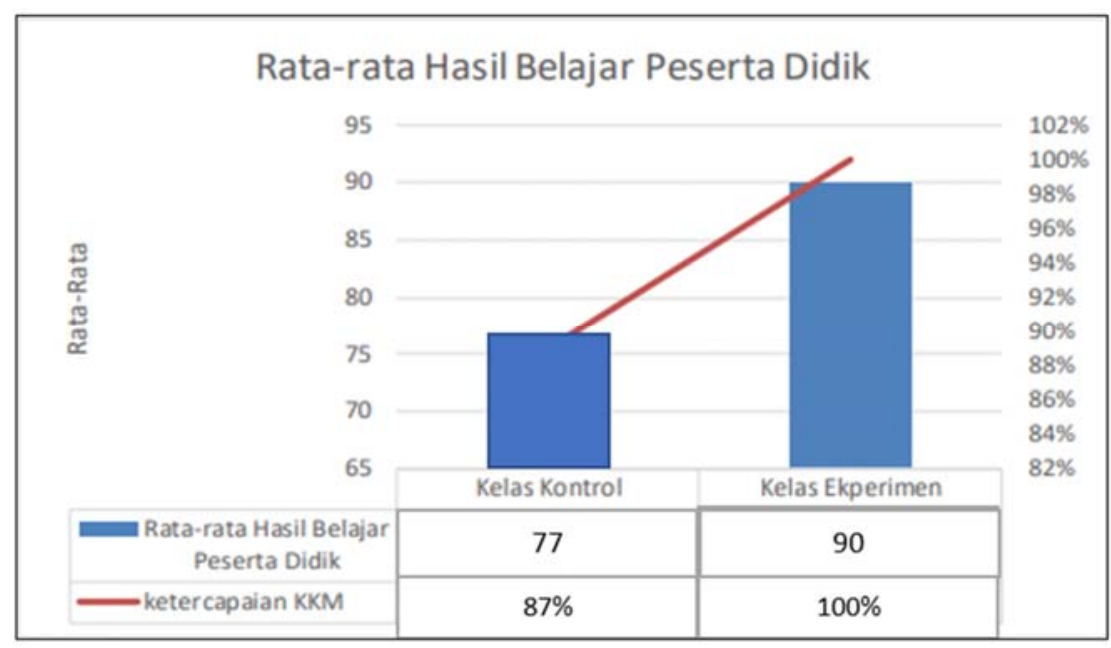

Gambar 4. Rata-rata Nilai Hasil Belajar Peserta Didik 
Berdasarkan paparan dalam Gambar 4 tersebut dapat dilihat bahwa hasil perhitungan posttest menunjukkan rata-rata hasil belajar peserta didik kelas eksperimen adalah 90 dan ketercapaian terhadap KKM mencapai $100 \%$ atau seluruh peserta didik memiliki nilai di atas KKM. Sedangkan rata-rata hasil belajar peserta didik kelas kontrol adalah 77 dan ketercapaian terhadap KKM mencapai 87\% atau terdapat empat peserta didik yang memiliki nilai di bawah KKM. Hal ini menunjukkan bahwa rata-rata belajar kelas eksperimen lebih tinggi daripada kelas kontrol.

Selanjutkan untuk mengukur perbedaan hasil belajar peserta didik antara kelas kontrol dan kelas eksperimen yang terdiri dari 67 peserta didik yaitu dengan menggunakan uji normalitas dan uji mann-whitney.

\subsection{Uji Prasyarat Analisis}

Hasil Uji Normalitas Data Hasil Belajar Peserta didik kelas kontrol dan kelas eksperimen

Tabel 4. Data Hasil Uji Normalitas Hasil belajar

\begin{tabular}{|c|c|c|c|c|c|c|c|}
\hline \multicolumn{8}{|c|}{ Tests of Normality } \\
\hline & \multirow[t]{2}{*}{ Kelas } & \multicolumn{3}{|c|}{ Kolmogorov-Smirnova } & \multicolumn{3}{|c|}{ Shapiro-Wilk } \\
\hline & & Statistic & df & Sig. & Statistic & Df & Sig. \\
\hline \multirow{3}{*}{$\begin{array}{l}\text { Hasil } \\
\text { Belajar }\end{array}$} & Kelas & .473 & 36 & .000 & .378 & 36 & .000 \\
\hline & Kontrol & & & & & & \\
\hline & $\begin{array}{l}\text { Kelas } \\
\text { Eksperimen }\end{array}$ & .349 & 35 & .000 & .739 & 35 & .000 \\
\hline
\end{tabular}

Table used by permission (CPurnamasari, Dwi Ike. 2021. Hasil uji normalitas hasil belajar.

Pada Tabel 4 menunjukkan bahwa data tingkat hasil belajar kelas Kontrol dan Eksperimen memiliki nilai signifikansi yaitu 0,000 kecil dari nilai $(\alpha=0,05)$ maka data dikatakan tidak terdistribusi normal, karena salah satu data tidak terdistribusi normal maka dilanjutkan dengan uji statistik nonparametrik menggunakan uji Mann-Whitney.

\subsection{Uji Mann-Whitney}

Tabel 5. Data Hasil Uji Mann-Whitney Hasil Belajar

\begin{tabular}{ll}
\hline \multicolumn{2}{c}{ Test Statistics $^{\mathbf{a}}$} \\
\hline & \\
Mann-Whitney U & Hasil Belajar Peserta Didik \\
Wilcoxon W & 62.500 \\
Z & 728.500 \\
Asymp. Sig. (2-tailed) & -6.562 \\
\end{tabular}

Table used by permission (CPurnamasari, Dwi Ike. 2021. Hasil uji mann-whitney hasil belajar.

Tabel 5 menunjukkan bahwa hasil uji Mann-Whitney yang diperoleh hasil dua sampel adalah 0,000 nilai ini lebih kecil dari nilai signifikan $(\alpha=0,05)$, sehingga probabilitas $<0,05$ (PValue $<0,05$ ), maka Ho ditolak yang berarti sehingga Hasil belajar peserta didik antara kelas eksperimen dan kelas kontrol terdapat perbedaan yang signifikan. Hasil penelitian ini relevan dengan penelitian yang dilakukan oleh sejumlah peneliti diantaranya oleh Firdausi and 
Santosa (2016) yang menunjukkan hasil bahwa hasil belajar siswa menggunakan media pembelajaran Mobile Learning (M-Learning) dengan berbantuan Smartphone Android pada kelas XI TAV 1 dinyatakan tuntas secara klasikal dengan persentase 80,64\%. Pengaruh media pembelajaran M-Learning terhadap hasil belajar peserta didik juga dibuktikan oleh Putra (2017) yang menunjukan bahwa media pembelajaran berbasis android dapat meningkatkan hasil belajar peserta didik secara signifikan, memiliki pengaruh positif dalam pembelajaran, dan terbukti memiliki perbedaan yang signifikan antara rata-rata hasil belajar kelas eksperimen dan kelas kontrol.

\section{Simpulan}

Penelitian dan pengembangan ini menghasilkan Mobile Learning PERSIKA berbasis iSpring Suite 9 pada mata pelajaran Administrasi Umum untuk meningkatkan Kemandirian dan hasil belajar peserta didik. Media pembelajaran ini bernama PERSIKA yang dapat diunduh dan di install melalui link manual https:// drive.google.com/file/d/13UXqlv1dBbqNHuPNWGZAlmCqMqhgTN/view? usp=drivesdk serta dapat akses secara offline.

Media pembelajaran pada penelitian ini telah dinyatakan 'Valid' dan layak digunakan dalam pembelajaran Administrasi Umum melalui validasi oleh ahli materi, ahli media serta uji coba kelompok kecil. Selain itu, Aplikasi PERSIKA ini disimpulkan bahwa terdapat perbedaan yang relevan dan juga dapat meningkatkan kemandirian dan hasil belajar peserta didik berdasarkan hasil uji Hitung manual. Aplikasi PERSIKA ini juga memungkinkan pembelajaran kapanpun dan dimanapun, bahkan secara mandiri tanpa harus terikat dengan kegiatan tatap muka di sekolah, sehingga aplikasi ini berguna ketika pembelajaran tidak dapat dilakukan dengan bertatap muka secara langsung seperti saat terjadi akibat adanya pandemi covid-19.

Aplikasi PERSIKA hanya berfokus pada satu kompetensi dasar dan terbatas pada sistem operasi android, sehingga diharapkan peneliti selanjutnya mengembangkan media pembelajaran pada sistem operasi lainnya seperti IOS.

\section{Ucapan Terima Kasih}

Penulis mengucapkan terimakasih kepada Universitas Negeri Malang dan SMK Muhammadiyah 5 Kepanjen Kabupaten Malang yang telah memfasilitasi dan memberi izin kepada peneliti untuk melakukan kegiatan penelitian dan pengembangan ini.

\section{Daftar Rujukan}

Afshari, M., Bakar, K.A., Luan, W.S., Samah, B.A., Fooi, F.S., (2009). Factors Affecting Teachers' Use of Information and Communication Technology. Online Submission, 2(1), 77-104.

Agbo, I.S., (2015). Factors Influencing the Use of Information and Communication Technology (ICT) in Teaching and Learning Computer Studies in Ohaukwu Local Government Area of Ebonyi State-Nigeria. Journal of Education and Practice 6(7). http://iiste.org/Journals/index.php/JEP/article/view/20674/21262

Crompton, H., Burke, D., (2018). The Use of Mobile Learning in Higher Education: A Systematic Review. Comput. Educ. 123, 53-64. Https://Doi.Org/10.1016/J.Compedu.2018.04.007

Damayanti, E., Rustiyarso, R., \& Rahmatika, I. EFEKTIVITAS PENGGUNAAN MEDIA ISPRING SUITE 8 TERHADAP HASIL BELAJAR SEJARAH KELAS X SMAN 5 PONTIANAK. Jurnal Pendidikan dan Pembelajaran Khatulistiwa, 7(9). Firdausi, R., Santosa, A.B., (2016). Pengembangan Media Pembelajaran Mobile Learning Berbantuan Smartphone Android pada Mata Pelajaran Perekayasaan Sistem Antena Studi pada Siswa Kelas XI TAV Smk Negeri 1 Nganjuk. Jurnal Pendidikan Teknik Elektro $05,7$.

Gandal, N., Kende, M., Rob, R., (2000). The Dynamics of Technological Adoption in Hardware/Software Systems: The Case of Compact Disc Players. The RAND Journal of Economics 31, 43-61. https://doi.org/10.2307/2601028 
Hendryadi, H., (2017). Validitas Isi: Tahap Awal Pengembangan Kuesioner. Jurnal Riset Manajemen dan Bisnis 2,169-178. https://doi.org/10.36226/jrmb.v2i2.47

Krishnamurthy, S., (2020). The future of business education: A commentary in the shadow of the Covid-19 pandemic. Journal of Business Research 117, 1-5. https://doi.org/10.1016/j.jbusres.2020.05.034

Lin, M.-H., (2017). A Study Of The Effects Of Digital Learning On Learning Motivation And Learning Outcome. Eurasia J. Math. Sci. Technol. Educ. 13. Https://Doi.Org/10.12973/Eurasia.2017.00744a

Meilasari, V., (2019). Pengaruh Penerapan Collaborative Learning Berbantu Ispring Presenter Terhadap Hasil Belajar Program Linear Eksponen, 9(2), 52-58.

Motiwalla, L.F., (2007). Mobile learning: A framework and evaluation. Computers \& Education 49, 581-596. https://doi.org/10.1016/j.compedu.2005.10.011

Muhson, A., (2010). Pengembangan Media Pembelajaran Berbasis Teknologi Informasi. Jurnal Pendidikan Akuntansi Indonesia 8. https://doi.org/10.21831/jpai.v8i2.949

Ngafifi, M., (2014). Kemajuan Teknologi Dan Pola Hidup Manusia Dalam Perspektif Sosial Budaya. Jurnal Pembangunan Pendidikan: Fondasi dan Aplikasi 2. https://doi.org/10.21831/jppfa.v2i1.2616

Nurwijayanti, A., Budiyono, Fitriana, L., (2018). The Use Of Interactive Media Ispring Suite 8 Supported By Google Sketchup To Improve Students' Geometry Skills Based On Hoffer's Theory. J. Phys. Conf. Ser. 1008, 012075. Https://Doi.Org/10.1088/1742-6596/1008/1/012075

Parsazadeh, N., Ali, R., Rezaei, M., (2018). A Framework For Cooperative And Interactive Mobile Learning To Improve Online Information Evaluation Skills. Comput. Educ. 120, 75-89. Https://Doi.Org/10.1016/J.Compedu.2018.01.010

Prasetyo, Z.K., N.D. (2017). Pengembangan Multimedia Pembelajaran IPA Interaktif Berbasis Lectora Inspire Untuk Meningkatkan Motivasi Dan Hasil Belajar Pend. Ilmu Pengetahuan Alam-S1, 6(6), 326-333 8.

Priansa, D.J., (2017). Pengembangan Strategi \& Model Pembelajaran Inovatif, Kreatif, Dan Prestatif Dalam Memahami Peserta Didik, 1st Ed. Cv Pustaka Mulia, Bandung.

Purwanto, P., Ramadhan, A.N., (2015). Pengembangan dan Unjuk Kerja Sistem Kearsipan Elektronik PSPAP. Efisiensi - Kajian Ilmu Administrasi 13, 31-65. https://doi.org/10.21831/efisiensi.v13i2.11676

Putra, K.W.B., Wirawan, I.M.A., Pradnyana, G.A., (2017). Pengembangan E-Modul Berbasis Model Pembelajaran Discovery Learning Pada Mata Pelajaran "Sistem Komputer" Untuk Siswa Kelas X Multimedia Smk Negeri 3 Singaraja. Jurnal Pendidikan Teknologi dan Kejuruan 14.

Rahmawati, E.M., Mukminan, M., (2017). Pengembangang M-Learning Untuk Mendukung Kemandirian Dan Hasil Belajar Mata Pelajaran Geografi. J. Inov. Teknol. Pendidik. 4, 157. Https://Doi.Org/10.21831/Jitp.V4i2.12726

Ratten, V., Jones, P., (2021). Covid-19 and entrepreneurship education: Implications for advancing research and practice. The International Journal of Management Education 100432. https://doi.org/10.1016/j.ijme.2020.100432

Sugiyono, (2009). Metode Penelitian Pendidikan. Alfabeta, Bandung.

Suryanda, dkk. (2016). Pengembangan Modul Multimedia Mobile Learning dengan Android Studio 4.1 Materi Keanekaragaman Hayati Bagi Siswa SMK Kelas X, Biosfer: Jurnal Pendidikan Biologi, 9(1), 55-64.

Swandhana, dkk . (2016). Meningkatkan Kemandirian Belajar dan Hasil Belajar Siswa melalui Pengembangan Modul Administrasi Kepegawaian Berbasis Strategi Pembelajaran Inkuiri Terbimbing. JPBM Jurnal Pendidikan Bisnis dan Manajemen), 2(3), 161-169.

Tabuenca, B., Kalz, M., Drachsler, H., Specht, M., (2015). Time will tell: The role of mobile learning analytics in self-regulated learning. Journal of Computers \& Education 89, 53-74. https://doi.org/10.1016/j.compedu.2015.08.004 